\title{
Prevalence and risk factors for low birth weight in Jordan and its association with under-five mortality: a population-based analysis
}

M. Mazharul Islam, ${ }^{1}$ Faisal Ababneh,,${ }^{1,2}$ Tahmina Akter ${ }^{3}$ and Hasinur Rahaman Khan ${ }^{3}$

${ }^{1}$ Department of Statistics, College of Science, Sultan Qaboos University, Muscat, Oman. ${ }^{2}$ Department of Mathematics, Al-Hussein Bin Talal University, Maan, Jordan. ${ }^{3}$ Applied Statistics, Institute of Statistical Research and Training, University of Dhaka, Dhaka, Bangladesh. (Correspondence to: M. Mazharul Islam: mmazhar.islam@yahoo.com, mislam@squ.edu.om).

\begin{abstract}
Background: Low birth weight $(<2.5 \mathrm{~kg})$ is an important indicator of health and development of infants throughout their life.

Aims: This study aimed to determine the prevalence and risk factors for low birth weight in Jordan and its association with under-5 mortality.

Methods: In this secondary analysis, data were extracted from the 2012 Jordan Population and Family Health Survey for 9734 live births born in the 5 years preceding the survey and for which birth weight was reported. Data were collected on child and maternal characteristics. Multivariable regression analysis was used to determine the significant risk factors for low birth weight and mortality.

Results: Of the 9734 births analysed, 13.8\% were low birth weight and 1.3\% were very low birth weight. Mother's age $(<30$ and $\geq 35$ years), education (less than higher education), birth interval ( $<24$ months and first birth), unplanned pregnancy, household wealth status (poorest and richest), consanguinity, residence (central and south regions of Jordan), female sex, birth order ( 1 and $\geq 6$ ), twin birth and maternal smoking during pregnancy were significant risk factors for low birth weight. The risk of death under 5 years of age was 4.8 times higher in children with low birth weight than children with normal birth weight.

Conclusions: The high rate of low birth weight and its increasing rate in Jordan is a challenge for public health. Preventing low birth weight neonates and increasing their survival need to be prioritized in the national health strategy. Special care needs to be taken for the high-risk groups identified in this study.

Keywords: low birth weight, risk factors, childhood mortality, Jordan

Citation: Islam MM; Ababneh F; Akter T; Khan HR. Prevalence and risk factors for low birth weight in Jordan and its association with under-five mortality: a population-based analysis. East Mediterr Health J. 2020;26(10):1273-1284. https://doi.org/10.26719/emhj.20.096

Received: 25/03/19; accepted: 16/10/19

Copyright @ World Health Organization (WHO) 2020. Open Access. Some rights reserved. This work is available under the CC BY-NC-SA 3.0 IGO license (https://creativecommons.org/licenses/by-nc-sa/3.o/igo)
\end{abstract}

\section{Introduction}

Low birth weight (LBW) has been defined by the World Health Organization (WHO) as a birth weight of less than $2500 \mathrm{~g}$ irrespective of gestational age $(1,2)$. This definition is mainly based on epidemiological observations to serve for international comparative health statistics. For clinical care the preferred definition is: small for gestational age defined as a weight and/or length less than -2 standard deviations (SD). However, ascertaining small for gestational age is not straightforward as it requires accurate measurement of anthropometry at birth including weight, length and head circumference (3).

Birth weight has long been a subject of clinical and epidemiological investigation and a target for public health interventions. In particular, considerable attention has been focused on the causes of LBW in order to identify potentially modifiable factors. LBW is one of the most important predictors of nutrition, health and survival of infants (2). LBW is also an important biomarker of adverse health and development problems in early and later life, including delays in cognitive and behavioural development, growth retardation, neurological problems in childhood, and many chronic diseases $(2,4-7)$. Babies with LBW have a 5-30 times higher risk of dying during infancy than normal birth weight ( $\geq 2500 \mathrm{~g}$ ) babies (2).

Globally, more than 20 million babies are born annually with LBW - about $15.5 \%$ of all live births (2). The incidence of LBW differs considerably between developed and developing countries. About $96 \%$ of newborns with LBW are born in developing countries - about $72 \%$ in Asia and $22 \%$ in Africa (2). The incidence of LBW in developing countries $(17 \%)$ is more than double the incidence in developed regions (7\%) (2). Thus, LBW is a particularly important public health problem in developing countries.

LBW can be a consequence of preterm birth (i.e. birth before 37 completed weeks of pregnancy), or intrauterine growth restriction, each of which is influenced by many factors related to the mother, the infant, the physical environment or genetics $(2,4,5,7)$. However, the pattern of risk factors for LBW and their relative contribution vary from one setting to another. It is therefore important to identify population-specific factors affecting LBW so that appropriate policy interventions can be formulated to improve child health and survival. 
While a considerable amount of research has been done on LBW - mostly in developed countries - LBW issues in developing countries, including Jordan, have not been adequately investigated. To fill this gap, we aimed to examine the prevalence, trends and determinants of LBW in Jordan. We also examined the effect of LBW on childhood mortality.

\section{Methods}

\section{Study design and sample}

This was a secondary analysis of data from the 2012 Jordan Population and Family Health Survey conducted as part of the Demographic and Health Survey (DHS) programme (8). The survey included a nationally representative sample of 11352 ever-married women aged 15-49 years from 15190 households. The fieldwork was carried out between 9 September and 20 December 2012.

The sample of the 2012 survey was designed to produce reliable estimates of major survey indicators for: the country as a whole; urban and rural areas; each of the 12 governorates; and two specific populations (people living in the Badia area and people living in refugee camps). The Badia area is where mostly Bedouin tribes, who used to lead a traditional nomadic life, live. This area includes both the arid and semi-arid area of Jordan which constitutes $80 \%$ of the total land area and $6.5 \%$ of the total population of the country lives there (9). Details of the survey methodology can be found in the final report of the 2012 Jordan Population and Family Health Survey (8).

\section{Data collected}

In the 2012 survey, all women interviewed were asked to provide a detailed history of all their live births in a chronological order, including birth weight of child born in the 5 years preceding the survey date, sex of child, date of birth, survival status and their own socioeconomic and demographic characteristics.

Our analysis was based on children born in the 5 years before the survey, whose birth weights were available. The 2012 Jordan Population and Family Health Survey provided birth weight records of 9734 such live births and these children were our study subjects.

\section{Variables}

We considered birth weight as the outcome variable and socioeconomic and demographic characteristics of mothers and the children as the explanatory variables. We used the WHO definition of LBW because direct measurement of birth weight was available in the 2012 Jordanian survey. Thus, a birth weight less than $2.5 \mathrm{~kg}$ was considered LBW and a birth weight less than $1.5 \mathrm{~kg}$ was considered very LBW (VLBW). A birth weight of $2.5 \mathrm{~kg}$ or more was considered normal birth weight (NBW). The explanatory variables were: mother's age at birth of the child $(<20$, $20-29,30-34$ and $\geq 35$ years), mother's education (no education, primary, secondary, higher), birth order of the child $(1,2-3,4-5,6)$, child's sex (male, female), type of birth (twin, singleton), birth interval since the previous birth
(<24 months, $\geq 24$ months, first birth), planned pregnancy (yes, no), region of residence (central, north, south), consanguineous marriage (yes,no), smoking during pregnancy (yes, no), and wealth index (lowest, second, middle, fourth, and highest quintiles). The wealth index, which is used by DHS globally, is a composite indicator of the economic status of the family (10), and is based on analysis of household assets such as possession of a television, refrigerator, car and household construction material. Smoking includes both cigarettes and use of the nargile (water pipe). All the above-mentioned socioeconomic and demographic variables were selected based on literature review and the availability of the data in the survey.

\section{Data analysis}

We used numbers and percentages to describe the characteristics of all births, and NBW, LBW and VLBW births. We used the chi-squared test to assess the significance of differences in birth weight according to socioeconomic or demographic factor. A P-value less than 0.05 was considered statistically significant.

To examine the association of LBW with childhood mortality, we considered the probability of death based on survival status and age at death for children in the age range 0 to 59 months (i.e. under 5 years) as the outcome variable. We categorized deaths as neonatal, postneonatal, infant and under-5 depending on age at death. Neonatal deaths were defined as those occurring within 28 days of birth among live births, post-neonatal deaths as those occurring between 28 days and $<12$ months, infant deaths as those occurring between birth and 12 months and under- 5 deaths as those occurring before 60 months of age. We estimated the neonatal, post-neonatal, infant and under-5 mortality rates for LBW babies and NBW babies by dividing the cumulative number of deaths in each age interval by the number of live births at the beginning of that interval. For example, the postneonatal mortality rate was estimated by dividing the number of deaths occurring between 28 days and $<12$ months by the number of live births minus the neonatal deaths, and then expressed per 1000 live births.

We used multiple logistic regression analysis to determine the factors associated with LBW and VLBW and also the risk of death in children with LBW compared with children with NBW. Socioeconomic and demographic variables that were significantly associated with LBW, VLBW and risk of death in children with LBW in the bivariate analysis (chi-squared test) were included in the logistic regression analysis. We calculated adjusted odds ratios (AOR) and 95\% confidence intervals (CI), controlling for all other socioeconomic and demographic variables that were significant in chi-squared test analysis.

\section{Ethical considerations}

The data from the Jordan Population and Family Health Survey are public access data and were made available to us by MEASURE DHS upon request. Informed consent was obtained from the respondents prior to the survey 
interview. Ethical clearance to conduct the Jordan Population and Family Health Survey was given by the Government of Jordan.

\section{Results}

\section{Sample characteristics}

More than half (56.4\% (5485)) of the children included in the analysis had mothers aged less than 30 years at the time of their birth, while 1894 (19.4\%) had mothers aged 35 years and older (Table 1). The mean (SD) age of mothers at the time of birth of the children was 28.8 (6.1) years. Most of the mothers had secondary education $(60.0 \%$ (5842), and 3084 (31.7\%) had higher education. This was the similar with the fathers: $6119(62.9 \%)$ of the fathers had secondary education and $2429(25.0 \%)$ had higher education. As regards birth order, 2282 (23.4\%) of the children were the first-born child and $3653(37.5 \%)$ were the fourth-born or more. Only 952 (9.8\%) of the pregnancies were unplanned, and the interval since the previous birth was less than 2 years for $2366(24.3 \%)$ of the children. Parental consanguinity was reported for $3288(33.8 \%)$ of the children, and 1412 mothers (14.5\%) smoked during pregnancy.

\section{Prevalence of and trends in LBW}

The mean (SD) birth weight of the infants born in the 5 years preceding the survey was $3090.4(663.8) \mathrm{g}$ or 3.09 (0.664) $\mathrm{kg}$. The prevalence of LBW $(<2500 \mathrm{~g})$ was $13.8 \%$ (1348/9734) in 2012, which included $123(1.3 \%)$ VLBW births $(<1500 \mathrm{~g})$. Thus, the prevalence of VLBW among the total LBW births was 9.1\% (Table 1).

Since 1990 there have been seven DHS conducted in Jordan. All these surveys followed the same methodology. The LBW rates estimated from these surveys show an increasing trend in LBW rates in Jordan (Figure 1). The prevalence of LBW increased from $8.8 \%$ in 1990 to $13.8 \%$ in 2012 - an increase of $57 \%$ over a period of 22 years $(t=9.96, P<0.001)(8,11-14)$.

\section{Predictors of LBW and VLBW}

In the bivariate analysis with the chi-squared test, all selected socioeconomic and demographic factors, except for urban/rural residence, were significantly associated with birth weight (Table 1). Young maternal age was significantly associated with LBW birth: $22.4 \%$ of LBW births were in mothers aged $<20$ years compared with mothers aged 30-34 years (10.9\%). VLBW births followed a similar maternal age pattern. Mothers' education showed a significant negative association with both LBW and VLBW: $18.3 \%$ of the LBW children were born to mothers with no education compared with $14.9 \%$ for mothers with a secondary education $(P<0.001)$. A greater proportion of LBW births were found in: first births than higher birth order $(P=0.04)$; females than males $(P<0.001)$; twins compared with singleton births $(P<0.001)$; mothers with a short birth interval $(<2$ years) compared with longer birth interval $(\geq 2$ years; $P<0.001)$; unplanned pregnancy $(P=0.002)$; consanguineous marriage $(P=0.043)$; and smoking $(P<0.001)$. Father's lack of education was also negatively associated with LBW $(P<0.001)$. Birth weight varied significantly across the three regions of Jordan: LBW was significantly higher in the South region than the North region $(P=0.002)$. Birth weight showed a significant but inconsistent pattern of association with the household wealth index. A greater proportion of mothers in the lowest and highest wealth quintiles had babies with LBW or VLBW than those with middle or fourth wealth quintiles.

To adjust for confounding of variables associated with LBW and VLBW, we used a multivariable logistic regression analysis (Table 2). Mother's age $(<30$ and $\geq 35$ years), education (less than higher education), birth interval (<24 months), unplanned pregnancy, households with lowest and highest wealth quintiles, consanguinity, residence in central and south regions, female sex of baby, birth order 1 and $\geq 6$, twin birth and maternal smoking during pregnancy were all significant risk factors for LBW. For VLBW, the statistically significant risk factors were: maternal age $20-29$ and $\geq 35$ years, primary education and less, birth order $2-3$ and $\geq 6$, female sex of baby, twin birth, unplanned pregnancy and residence in the central region.

\section{LBW and childhood mortality}

Of the 9734 live births with information on birth weight, 172 died during childhood (i.e. aged 0-59 months). Thus, the overall mortality rate was 17.67 deaths per 1000 live births under the age of 5 years. The corresponding rates for children with LBW and NBW were 57.86 per 1000 live births and 11.21 per 1000 live births, respectively (Table 3), a statistically significant difference $(P<0.001)$. Thus, children with LBW had a 5.16 times higher mortality rate in childhood than children with NBW.

Mortality rates of children with LBW were significantly higher than the mortality rates of children with NBW in all age ranges under the age of 5 years. For example, the infant mortality rate was 54.9 deaths per 1000 live births in infants born with LBW compared with 8.7 deaths per 1000 live births in infants born with NBW - a 6.3 times higher mortality for infants born with LBW $(P<0.001)$. It is worth mentioning here that most $(76 \%)$ of the deaths under age 5 years of age had occurred in the neonatal period. This was true for both the LBW and NBW babies. However, this proportion $(88.5 \%)$ for LBW babies was significantly higher than the proportion (64.9\%) for NBW babies (95\% CI for the difference: 0.116$0.355 ; P<0.001$ ), indicating a greater influence of LBW on death during the neonatal period. The neonatal mortality rate was 7.0 times higher in LBW babies than NBW babies (51.19 versus 7.27 deaths per 1000 live births) and the difference was statistically significant $(P<0.001)$.

The adjusted analysis using multiple logistic regression analysis showed LBW to be a strong predictor of childhood mortality (Table 3). The risk of all types of childhood death, except post-neonatal death, was significantly higher in children born with LBW than children born with NBW. The greatest effect of birth 


\begin{tabular}{|c|c|c|c|c|c|}
\hline Characteristic & All live births & $\begin{array}{l}\text { Normal birth } \\
\text { weight }\end{array}$ & Low birth weight ${ }^{\mathrm{a}}$ & $\begin{array}{l}\text { Very low birth } \\
\text { weight }\end{array}$ & P-value ${ }^{\mathrm{b}}$ \\
\hline & No. (\%) & No. $(\%)$ & No. (\%) & No. (\%) & \\
\hline Total & $9734(100)$ & $8386(86.2)$ & $1348(13.8)$ & $123(1.3)$ & \\
\hline $\begin{array}{l}\text { Mother's age at birth of child } \\
\text { (years) }\end{array}$ & & & & & $<0.001$ \\
\hline$<20$ & $424(4.4)$ & $329(77.6)$ & $95(22.4)$ & $9(2.1)$ & \\
\hline $20-29$ & $5061(52.0)$ & $4327(85.5)$ & $734(14.5)$ & $79(1.6)$ & \\
\hline $30-34$ & $2355(24.2)$ & $2099(89.1)$ & $256(10.9)$ & $15(0.6)$ & \\
\hline$\geq 35$ & $1894(19.5)$ & $1631(86.1)$ & $263(13.9)$ & $20(1.1)$ & \\
\hline Mean (SD) & $28.8(6.1)$ & $29.0(6.0)$ & $28.2(6.4)$ & $27.8(5.9)$ & \\
\hline Mother's education & & & & & $<0.001$ \\
\hline No education & $190(2.0)$ & $155(81.2)$ & $35(18.3)$ & $6(3.1)$ & \\
\hline Primary & $618(6.3)$ & $508(82.2)$ & $110(17.8)$ & $9(1.5)$ & \\
\hline Secondary & $5842(60.0)$ & $4972(85.1)$ & $870(14.9)$ & $77(1.3)$ & \\
\hline Higher & $3084(31.7)$ & $2751(89.2)$ & $333(10.8)$ & $31(1.0)$ & \\
\hline Birth order & & & & & 0.004 \\
\hline 1 & $2282(23.4)$ & $1914(83.9)$ & $368(16.1)$ & $43(1.9)$ & \\
\hline $2-3$ & 3799 (39.0) & $3286(86.5)$ & $513(13.5)$ & $52(1.4)$ & \\
\hline $4-5$ & $2347(24.1)$ & $2056(87.6)$ & $291(12.4)$ & $18(0.8)$ & \\
\hline$\geq 6$ & $1306(13.4)$ & $1130(86.5)$ & $176(13.5)$ & $10(0.8)$ & \\
\hline Mean (SD) & $3.22(2.1)$ & $3.24(2.1)$ & $3.11(2.0)$ & $2.57(1.8)$ & \\
\hline Child's sex & & & & & $<0.001$ \\
\hline Male & $5074(52.1)$ & $4493(88.5)$ & $581(11.5)$ & $41(0.8)$ & \\
\hline Female & $4660(47.9)$ & $3893(83.5)$ & $767(16.5)$ & $82(1.8)$ & \\
\hline Type of birth & & & & & $<0.001$ \\
\hline Singleton & $9391(96.5)$ & $8234(87.7)$ & $1157(12.3)$ & $87(0.9)$ & \\
\hline Twin & $343(3.5)$ & $152(44.3)$ & $191(55.7)$ & $36(10.5)$ & \\
\hline Planned pregnancy & & & & & 0.002 \\
\hline Yes & $8781(90.2)$ & $7601(86.6)$ & $1180(13.4)$ & $104(1.2)$ & \\
\hline No & $952(9.8)$ & $785(82.4)$ & $167(17.5)$ & $19(2.0)$ & \\
\hline Birth interval & & & & & $<0.001$ \\
\hline$<24$ months & $2366(24.3)$ & $2030(85.8)$ & $336(14.2)$ & $21(0.9)$ & \\
\hline$\geq 24$ months & $5032(51.7)$ & $4398(87.3)$ & $636(12.6)$ & $49(1.0)$ & \\
\hline First birth & $2332(24.0)$ & $1958(84.0)$ & $374(16.0)$ & $53(2.3)$ & \\
\hline Father's education & & & & & $<0.001$ \\
\hline No education & $99(1.0)$ & $80(80.8)$ & $19(19.2)$ & $1(1.0)$ & \\
\hline Primary & $1087(11.2)$ & $883(81.2)$ & $204(18.8)$ & $12(1.1)$ & \\
\hline Secondary & $6119(62.9)$ & $5317(86.9)$ & $802(13.1)$ & $86(1.4)$ & \\
\hline Higher & $2429(25.0)$ & $2106(86.7)$ & $323(13.3)$ & $24(1.0)$ & \\
\hline Region & & & & & 0.002 \\
\hline Central & $5950(61.1)$ & $5102(85.7)$ & $848(14.3)$ & $60(1.0)$ & \\
\hline North & $2843(29.2)$ & $2482(87.3)$ & $361(12.7)$ & $48(1.7)$ & \\
\hline South & $941(9.7)$ & $802(85.2)$ & $139(14.8)$ & $15(1.6)$ & \\
\hline Place of residence & & & & & 0.564 \\
\hline Urban & $7926(81.4)$ & $6822(86.1)$ & $1104(13.9)$ & $97(1.2)$ & \\
\hline Rural & 1808 (18.6) & $1564(86.5)$ & 244 (13.5) & $26(1.4)$ & - \\
\hline
\end{tabular}


Table 1 Distribution of all live births in the 5 years preceding the survey and birth weight according to background characteristics (Concluded)

\begin{tabular}{|c|c|c|c|c|c|}
\hline \multirow[t]{2}{*}{ Characteristic } & All live births & $\begin{array}{l}\text { Normal birth } \\
\text { weight }\end{array}$ & Low birth weight ${ }^{a}$ & $\begin{array}{c}\text { Very low birth } \\
\text { weight }\end{array}$ & P-value ${ }^{b}$ \\
\hline & No. (\%) & No. (\%) & No. (\%) & No. (\%) & \\
\hline Wealth index (centile) & & & & & 0.046 \\
\hline Lowest & $2230(22.9)$ & $1879(84.3)$ & $351(15.7)$ & $29(1.3)$ & \\
\hline Second & $2166(22.3)$ & $1860(85.9)$ & $306(14.1)$ & $33(1.5)$ & \\
\hline Middle & $2103(21.6)$ & $1846(87.8)$ & $257(12.2)$ & $22(1.0)$ & \\
\hline Fourth & $1880(19.3)$ & $1637(87.1)$ & $243(12.9)$ & $21(1.1)$ & \\
\hline Highest & $1354(13.9)$ & $1163(85.9)$ & $191(14.1)$ & $18(1.3)$ & \\
\hline Consanguinity & & & & & 0.043 \\
\hline Yes & $3288(33.8)$ & $2809(85.4)$ & $479(14.6)$ & $43(1.3)$ & \\
\hline No & $6446(66.2)$ & $5577(86.5)$ & $869(13.5)$ & $80(1.2)$ & \\
\hline Smoking during pregnancy & & & & & $<0.001$ \\
\hline No & $8322(85.5)$ & $7232(86.9)$ & $1090(13.1)$ & $96(1.2)$ & \\
\hline Yes & $1412(14.5)$ & $1154(81.7)$ & $258(18.3)$ & $27(1.9)$ & \\
\hline
\end{tabular}

SD: standard deviation.

${ }^{a}$ Low birth weight includes very low birth weight also.

${ }^{b}$ Chi-squared test.

The number of missing values may vary for each variable.

Source: Jordan Population and Family Health Survey, 2012 (9).

weight on death was in the neonatal (age 0-1 month) period: neonatal deaths were 6 times higher in babies born with LBW than those born with NBW $(\mathrm{OR}=6.09$, 95\% CI: 4.17-8.91).

\section{Discussion}

It is encouraging to note that birth weight data from Jordan Population and Family Health Survey were available for $99 \%$ of births occurring in the 5 years preceding the survey. The availability of birth weight data for almost all infants in Jordan is not surprising because most deliveries in the country take place in health facilities, where health personnel usually weigh the newborn and record the weight on a health card.

The mean (SD) birth weight of the children in our analysis was $3.09(0.66) \mathrm{kg}$, which is lower than the newborns on the United States of America $(3.45 \mathrm{~kg}$ ) on whom WHO's reference standard is based (15).

The estimated prevalence of LBW in Jordan was $13.8 \%$ in 2012, which is higher than the average incidence of LBW of $7.0 \%$ in developed countries, but lower than the average incidence of LBW of about $17.0 \%$ in developing countries (2).Although, 2019 LBW estimates indicated that the global estimate of LBW had declined since 2000 (16), our results show an increasing trend in LBW in Jordan from $8.8 \%$ in 1990 to $13.8 \%$ in 2012 , a $57 \%$ increase. Various reasons have been put forward to explain increasing trends in LBW, which include epidemiological transition, change in lifestyle and food habits, improvement in medical technology, and increasing trends in premature and twin births (17-20). During pregnancy, mothers' metabolic demands increase due to modifications in mothers' physiology and the requirements of a growing fetus (21).
Epidemiological transition, change in lifestyle and food habits or nutritional intake have many dimensions that affect maternal metabolism. Epidemiological transition such as increased cardiovascular disease, type 2 diabetes, blood pressure and osteoporosis are associated with adverse pregnancy outcomes including LBW (20-22). Lifestyle behaviours such as cigarette smoking, alcohol and drug use, weight gain during pregnancy, physical activity and stress play important roles in determining fetal growth $(23,24)$. There is much evidence supporting the link between inadequate maternal nutritional status and adverse pregnancy outcomes (25-28). Detailed

Figure 1 Trends in low birth weight in Jordan, 1990-2012 Source: Calculated using data from Jordan Population and Family Health Surveys, 1990-2012 (8,11-14)

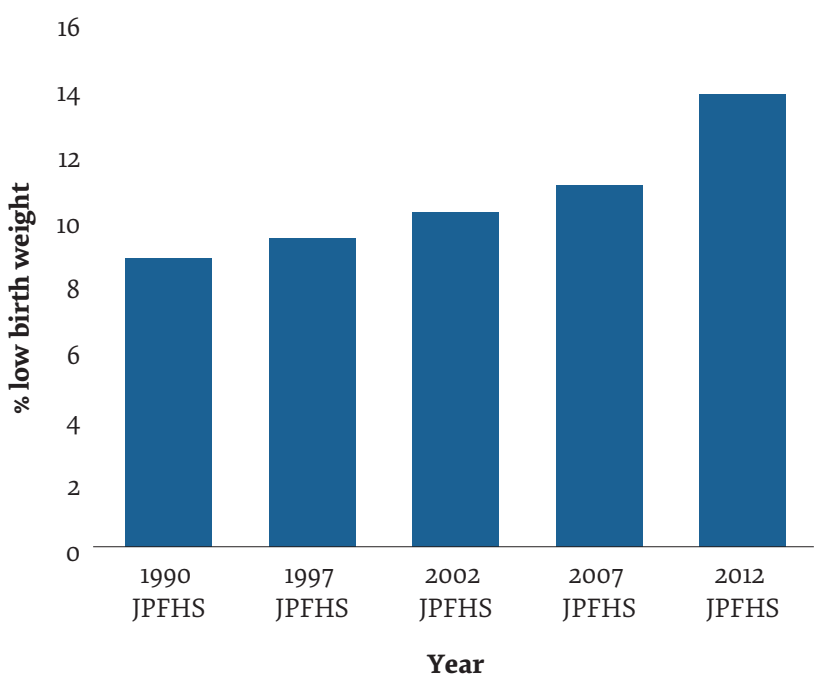




\begin{tabular}{|c|c|c|c|c|c|c|}
\hline \multirow[t]{2}{*}{ Variable } & \multicolumn{3}{|c|}{ Low birth weight } & \multicolumn{3}{|c|}{ Very low birth weight } \\
\hline & $\begin{array}{c}\beta \\
\text { coefficient }\end{array}$ & P-value & $\begin{array}{l}\text { Adjusted OR }{ }^{\mathrm{a}} \\
(95 \% \mathrm{CI})\end{array}$ & $\begin{array}{c}\beta \\
\text { coefficient }\end{array}$ & P-value & $\begin{array}{l}\text { Adjusted OR } \\
\qquad(95 \% \mathrm{CI})\end{array}$ \\
\hline \multicolumn{7}{|c|}{$\begin{array}{l}\text { Mother's age at birth of child } \\
\text { (years) }\end{array}$} \\
\hline$<20$ & 0.726 & $<0.001$ & $2.07(1.52-2.81)$ & 0.767 & 0.107 & $2.15(0.85-5.47)$ \\
\hline $20-29$ & 0.331 & $<0.001$ & $1.39(1.17-1.66)$ & 0.715 & 0.024 & $2.04(1.10-3.80)$ \\
\hline $30-34$ (ref) & & & 1.00 & & & 1.00 \\
\hline$\geq 35$ & 0.326 & 0.002 & $1.38(1.13-1.71)$ & 0.963 & 0.012 & $2.62(1.24-5.53)$ \\
\hline \multicolumn{7}{|l|}{ Mother's education } \\
\hline No education & 0.675 & 0.002 & $1.97(1.28-3.03)$ & 1.564 & 0.003 & $4.78(1.70-13.41)$ \\
\hline Primary & 0.592 & $<0.001$ & $1.81(1.38-2.37)$ & 0.845 & 0.045 & $2.33(1.02-5.32)$ \\
\hline Secondary & 0.411 & $<0.001$ & $1.51(1.29-1.77)$ & 0.454 & 0.064 & $1.57(0.97-2.54)$ \\
\hline Higher (ref) & & & 1.00 & & & 1.00 \\
\hline \multicolumn{7}{|l|}{ Father's education } \\
\hline No education & 0.170 & 0.142 & $1.18(0.94-1.49)$ & 0.165 & 0.535 & $1.18(0.70-1.98)$ \\
\hline Primary & -0.190 & 0.081 & $0.83(0.70-1.15)$ & -0113 & 0.783 & $0.89(0.40-1.99)$ \\
\hline Secondary & -0.287 & 0.379 & $0.75(0.39-1.42)$ & -0.806 & 0.441 & $0.44(0.06-3.47)$ \\
\hline Higher (ref) & & & 1.00 & & & 1.00 \\
\hline \multicolumn{7}{|l|}{ Birth order } \\
\hline 1 & 0.304 & 0.027 & $1.36(1.08-3.01)$ & 0.630 & 0.272 & $1.88(0.61-5.78)$ \\
\hline $2-3$ & -0.685 & 0.066 & $0.50(0.24-1.05)$ & 0.716 & 0.028 & $2.05(1.08-3.87)$ \\
\hline $4-5$ (ref) & & & 1.00 & & & 1.00 \\
\hline$\geq 6$ & 0.243 & 0.009 & $1.28(1.10-2.92)$ & -0.889 & 0.048 & $0.41(0.17-0.99)$ \\
\hline \multicolumn{7}{|l|}{ Child's sex } \\
\hline Male (ref) & & & 1.00 & & & 1.00 \\
\hline Female & 0.415 & $<0.001$ & $1.51(1.34-1.71)$ & 0.773 & $<0.001$ & $2.16(1.46-3.20)$ \\
\hline \multicolumn{7}{|l|}{ Type of birth } \\
\hline Singleton (ref) & & & 1.00 & & & 1.00 \\
\hline Twin & 2.226 & $<0.001$ & $9.26(7.22-11.88)$ & 2.660 & $<0.001$ & $14.30(8.68-23.54)$ \\
\hline \multicolumn{7}{|l|}{ Planned pregnancy } \\
\hline Yes (ref) & & & 1.00 & & & 1.00 \\
\hline No & 0.419 & $<0.001$ & $1.52(1.23-1.88)$ & 1.186 & $<0.001$ & $3.27(1.74-6.16)$ \\
\hline \multicolumn{7}{|l|}{ Birth interval } \\
\hline$<24$ months & 0.196 & 0.047 & $1.22(1.06-1.54)$ & 0.082 & 0.776 & $1.08(0.62-1.91)$ \\
\hline$\geq 24$ months (ref) & & & 1.00 & & & 1.00 \\
\hline First birth & 1.071 & 0.003 & $2.92(1.45-4.68)$ & 0.572 & 0.213 & $1.77(0.72-4.36)$ \\
\hline \multicolumn{7}{|c|}{ Wealth index (quintiles) } \\
\hline Lowest & 0.178 & 0.047 & $1.19(1.07-1.78)$ & 0.121 & 0.700 & $1.12(0.61-2.08)$ \\
\hline Second & 0.044 & 0.644 & $1.05(0.87-1.26)$ & 0.310 & 0.286 & $1.36(0.77-2.41)$ \\
\hline Middle (ref) & & & 1.00 & & & 1.00 \\
\hline Fourth & 0.067 & 0.512 & $1.07(0.88-1.31)$ & 0.255 & 0.426 & $1.29(0.69-2.42)$ \\
\hline Highest & 0.221 & 0.035 & $1.25(1.06-1.61)$ & 0.532 & 0.138 & $1.70(0.84-3.44)$ \\
\hline \multicolumn{7}{|l|}{ Region } \\
\hline Central & 0.148 & 0.043 & $1.16(1.00-1.34)$ & -0.502 & 0.018 & $0.61(0.40-0.92)$ \\
\hline South & 0.285 & 0.012 & $1.33(1.07-1.66)$ & 0.116 & 0.713 & $1.12(0.61-2.08)$ \\
\hline North (ref) & & & 1.00 & & & 1.00 \\
\hline \multicolumn{7}{|l|}{ Consanguinity } \\
\hline Yes & 0.149 & 0.024 & $1.16(1.02-1.32)$ & 0.280 & 0.174 & $1.32(0.88-1.98)$ \\
\hline No (ref) & & & 1.00 & 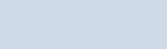 & 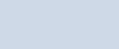 & 1.00 \\
\hline
\end{tabular}




\begin{tabular}{|c|c|c|c|c|c|c|}
\hline \multirow[t]{2}{*}{ Variable } & \multicolumn{3}{|c|}{ Low birth weight } & \multicolumn{3}{|c|}{ Very low birth weight } \\
\hline & $\begin{array}{c}\beta \\
\text { coefficient }\end{array}$ & P-value & $\begin{array}{l}\text { Adjusted OR }{ }^{a} \\
\quad(95 \% \mathrm{CI})\end{array}$ & $\begin{array}{c}\beta \\
\text { coefficient }\end{array}$ & P-value & $\begin{array}{l}\text { Adjusted OR }{ }^{\mathrm{a}} \\
\quad(95 \% \mathrm{CI})\end{array}$ \\
\hline \multicolumn{7}{|c|}{ Smoking during pregnancy } \\
\hline No (ref) & & & 1.00 & & & 1.00 \\
\hline Yes & 0.312 & $<0.001$ & $1.37(1.16-1.64)$ & 0.364 & 0.134 & $1.44(0.89-2.32)$ \\
\hline
\end{tabular}

OR: Odds ratio; CI: confidence interval; ref: reference category.

${ }^{a}$ Adjusted for socioeconomic, demographic and behavioural characteristics.

discussion on these issues is beyond the scope of our study. However, more research is needed to ascertain the underlying factors responsible for this increasing trend in LBW in Jordan. At the same time, appropriate interventions aimed at preventing LBW need to be taken immediately.

An important objective of our study was to identify the factors significantly associated with LBW in Jordan. We identified maternal age, maternal education, birth interval, consanguinity of the parents, maternal smoking, household wealth status, region of residence, birth order, sex of child and type of birth (twin/singleton) as significantly associated with LBW in Jordan. In agreement with many earlier studies, we found an increased risk of having a LBW baby in mothers younger than 20 years of age (29-31). This result is consistent with the finding of a study in North Jordan (32). The risk of LBW, however, showed a U-shaped pattern in relation to maternal age. A number of studies have noted that LBW increases at the two extremes of women's reproductive life, that is, $<20$ years and $\geq 35$ years (29-31). As with maternal age, birth order also showed a U-shaped relationship with the risk of LBW, which is consistent with the finding of others studies $(33,34)$. The higher risk of LBW in mothers aged $<20$ years or with first births, and older mothers or with higher order births might be due to reproductive and anatomical problems, lack of proper knowledge and use of antenatal care, low socioeconomic status, unplanned pregnancies and more pregnancy complications $(29,35)$.

Mother's education might affect birth weight directly or indirectly through acquired knowledge of health processes such as antenatal care and nutrition. The results of our analysis are also similar to previous studies that showed that illiterate mothers were at a higher risk of delivering LBW babies than literate mothers $(7,17,36)$. We did not find father's illiteracy a risk for LBW as compared with higher educated fathers which is contrary to earlier research (37).

Our results showed that mother's low economic status was an important risk factor for LBW. This finding is in agreement with previous studies which showed that poor economic status increased the risk of delivering a LBW baby $(36,38)$. The effect of low economic status may be the sum of many unfavourable conditions that increase the risk of adverse pregnancy outcomes. Contrary to the findings of most other studies, our analysis also found a higher risk of having a LBW baby among the richest group of mothers compared with the middle-income group. It is possible that smoking and bearing children when 35 years or older are more prevalent among mothers in the higher economic group, which increase their risk of having LBW babies. Furthermore, contrary to the developed societies, mothers in developing and transitional societies who are of higher socioeconomic status are more likely to lead a sedentary life and consume high-calorie foods,

\begin{tabular}{|c|c|c|c|c|c|c|}
\hline \multirow[t]{2}{*}{ Age period at death ${ }^{\mathrm{a}}$} & \multicolumn{4}{|c|}{ Death rate per 1000 live births ${ }^{b}$} & \multicolumn{2}{|c|}{ Risk of death } \\
\hline & $\begin{array}{c}\text { LBW } \\
(n=1348)\end{array}$ & $\begin{array}{c}\text { NBW } \\
(n=8386)\end{array}$ & All $(n=9734)$ & $P$-value ${ }^{c}$ & $\begin{array}{l}\text { Adjusted OR }^{\mathrm{d}} \\
\quad(95 \% \mathrm{CI})\end{array}$ & P-value \\
\hline Neonatal & $51.19(69)$ & $7.27(61)$ & $13.36(130)$ & $<0.001$ & $6.09(4.17-8.91)$ & $<0.001$ \\
\hline Post-neonatal & $3.91(5)$ & $1.44(12)$ & $1.77(17)$ & 0.051 & $2.41(0.79-7.35)$ & 0.123 \\
\hline Infant & $54.90(74)$ & $8.70(73)$ & $15.10(147)$ & $<0.001$ & $5.57(3.89-7.97)$ & $<0.001$ \\
\hline Under-5 & $57.86(78)$ & $11.21(94)$ & $17.67(172)$ & $<0.001$ & $4.83(3.45-6.77)$ & $<0.001$ \\
\hline
\end{tabular}

LBW: low birth weight; NBW: normal birth weight; OR: odds ratio; CI: confidence interval.

${ }^{a}$ Neonatal deaths occurred within 28 days of birth; post-neonatal deaths occurred between 28 days and $<12$ months; infant deaths occurred between birth and 12 months; and under-5 deaths occurred before 60 months of age.

${ }^{b}$ Figures in parenthesis are the number of deaths reported.

'P-values are based on t-test comparing proportion of deaths between LBW and NBW.

${ }^{d}$ Adjusted for maternal age, education, household wealth status, birth order, sex of child, birth type (singleton/twin), region of residence and place of residence (urban/rural).

Source: Jordan Population and Family Health Survey, 2012 (9). 
which increase their likelihood of becoming obese and suffering from chronic diseases $(39,40)$, and consequently having LBW babies.

Female babies had a higher risk of LBW than male babies, which is in agreement with other studies $(41,42)$. Globally, it is well known that birth weight in boys is higher than in girls in the general population, but the underlying mechanisms are poorly understood. Some studies have suggested that the gender difference in birth weight is partly because of prenatal androgen action $(43,44)$. Cell divisions in male embryos have been observed to occur more rapidly than those of female embryos and this may play a role in gender difference in birth weight (45). During pregnancy, if a mother knows the sex of her baby before birth, maternal discriminatory behaviour could also make a difference in birth weight. This has been observed in a previous study in Jordan where the mother's pre-birth knowledge of the sex of her baby influenced her diet and psychological well-being in favour of a male fetus (46). Consanguineous marriage, which is prevalent in Jordan (35\%) (47), was a significant risk factor for LBW. Some research has also reported a higher risk of LBW in mothers in a consanguineous marriage (48), while other research has found no significant association (49).

Our finding that a shortbirth interval was an important risk factor for LBW is consistent with the findings of previous studies $(50,51)$. In addition, twin pregnancies had an almost 10 times higher risk of resulting in LBW in our analysis. It is likely that many of the twins were premature births. A recent study showed that the rate twin pregnancies has increased in Jordan, from $2.4 \%$ in 1990 to $3.5 \%$ in 2012 (52), which may partly explain the reason for increasing trends in LBW in Jordan.

A substantial proportion of mothers (14.5\%) included in our analysis smoked during pregnancy. This rate is comparable to the prevalence of smoking in pregnant women in developed countries, for example, $10.7 \%$ in the United States (53), 18.0\% in Spain (54) and 19.9\% in Poland (55). The prevention of smoking and exposure to smoking during pregnancy is an important global issue and requires further research. Maternal smoking was associated with LBW in our study, which concurs with the findings of many previous studies about the adverse effects of smoking exposure on pregnancy outcomes (56-58).

Our analysis identified LBW as a very strong predictor of childhood mortality. Children born with LBW had a 4.8 times higher mortality rate during their first 5 years compared with children born with NBW. The greatest effect of birth weight on mortality was in the neonatal period. The risk of death of LBW babies in the neonatal period was 6 times higher than NBW babies. Although LBW babies comprise about $14 \%$ of all children born in Jordan, they account for more than half (53\%) of neonatal deaths in the country.With advances in modern obstetric and neonatal care and technological development across the world including in Jordan, doctors today are able to keep smaller premature babies alive (19). Because of this, more and more LBW babies are being reported as live births. However, these new survivors remain at a higher risk of health and developmental problems, and these babies may not survive to their first birthday and through their childhood period, resulting a higher mortality among LBW babies.

Our study has some limitations. We could not control for several important variables, such as maternal weight gain during pregnancy, health status, food consumption, diet and lifestyle, as the survey did not collect information on these variables. Some other important variables, such as antenatal care use, maternal body mass index, could not be used because data were missing for very many women. Nevertheless, the study has several strengths. It is based on data from a national survey that used sound methodology and validated questionnaires. The survey covered a large number of socioeconomic, demographic and health-related variables. The findings of the study are generalizable to the whole country as the analysis is based on nationally representative survey data. The findings of our analysis may help identify vulnerable groups of the population at risk of having LBW babies and in need of support to prevent adverse pregnancy outcomes. Our findings may also be used to guide policy for reduction of LBW and improved survival of LBW babies.

\section{Conclusion}

The high rate of LBW and its increasing rate in Jordan is a new challenge for public health in the country. Our finding of very high neonatal mortality in LBW babies deserves attention by the national child health care programme. The causes of high neonatal mortality in infants in general, and LBW infants in particular, need to be identified to help direct appropriate interventions to reduce neonatal mortality in Jordan. Prevention of LBW and the development of strategies to increase the survival of LBW neonates are the two important tasks for the government of Jordan. The first task includes efforts to develop early risk-assessment programmes through prenatal care services, health education, counselling and proper management of peripartum complications. Services should also be provided for mothers with a high risk of having a LBW baby such as young (age $<20$ years) and primiparous mothers, mothers with twin pregnancy or no education or mothers who smoke. The second task to increase the survival of LBW infants requires clinicians to develop new management strategies including setting up neonatal intensive care units, and applying kangaroo techniques and intensive breastfeeding for LBW babies. The significantly higher prevalence of LBW in the South region of Jordan underscores the need for special attention to this region to find solutions to reduce this disparity. 


\section{Acknowledgement}

We thank MEASURE DHS for granting access to Jordan Population and Family Health Survey datasets. The views expressed herein are those of the authors and do not necessarily reflect the views of any institution or organization.

Funding: None.

Competing interests: None declared.

\section{Prévalence et facteurs de risque pour l'insuffisance pondérale à la naissance en Jordanie et son lien avec la mortalité des moins de cinq ans : une analyse populationnelle}

\section{Résumé}

Contexte : Un faible poids de naissance (poids inférieur à 2,5kg) est un indicateur majeur de santé et de développement du nourrisson tout au long de sa vie.

Objectifs : La présente étude visait à déterminer la prévalence et les facteurs de risque de l'insuffisance pondérale à la naissance en Jordanie et son association avec la mortalité des moins de cinq ans.

Méthodes: Dans cette analyse secondaire, les données ont été extraites de l'Enquête jordanienne de 2012 sur la population et la santé de la famille, pour 9734 naissances vivantes au cours des cinq années précédant l'enquête, et pour lesquelles le poids de naissance était indiqué. Les données ont été recueillies au sujet des caractéristiques maternelles et infantiles. Une analyse de régression multivariée a été utilisée pour déterminer les facteurs de risques significatifs d'une insuffisance pondérale à la naissance.

Résultats : Parmi les 9734 naissances analysées, 13,8\% présentaient un poids de naissance faible et 1,3\% un poids de naissance très faible. Lâge de la mère (inférieur à 30 ans et supérieur ou égal à 35 ans), le niveau d'instruction (moins que l'enseignement supérieur), l'intervalle entre les naissances (moins de 24 mois après la première naissance), la grossesse non planifiée, le niveau de richesse du ménage (pauvre ou riche), la consanguinité, le lieu de résidence (régions centrale et sud de la Jordanie), le sexe féminin, l'ordre de naissance de 1 à 6 ou plus, la naissance gémellaire et le tabagisme maternel pendant la grossesse étaient des facteurs de risque significatifs de l' insuffisance pondérale à la naissance. Le risque de mortalité des moins de cinq ans était 4,8 fois plus élevé chez les enfants ayant eu un faible poids de naissance que chez ceux ayant eu un poids de naissance normal.

Conclusions : Le taux élevé d'insuffisance pondérale à la naissance et son augmentation constituent un problème de santé publique en Jordanie. Il est nécessaire de mettre en place en urgence une stratégie sanitaire nationale assurant aux nouveau-nés un poids de naissance normal et ainsi leur survie. Les groupes à haut risques tels que définis par la présente étude doivent faire l'objet d'une attention particulière.

$$
\begin{aligned}
& \text { معدل انتشار انخفاض الوزن عند الولادة وعوامل الخطر المرتبطة به في الأردن، وارتباطه بوَفَيَات الأطفال دون سن الخان } \\
& \text { الخامسة: تحليل مستند إلى السكان أنسان } \\
& \text { مظهرول إسلام، فيصل أبابنيه، تهمينا أكتي، هاسينور خان } \\
& \text { الخلاصة } \\
& \text { الخلفية: يُعد انخفاض الوزن عند الو لادة (أقل من } 2.5 \text { كجم) مؤشراً مهاً على صحة الرَُّّع ونموهم طو ال حياتهم. } \\
& \text { الأهداف: هدفت هذه الدر اسة إلى تحديد معدل انتشار انخفاض الوزن عند الو لادة، وعو امل الخطر المرتبطة به في الأردن، وارتباطه بوَفَيَات الأطفال } \\
& \text { دون سن الخامسة. }
\end{aligned}
$$

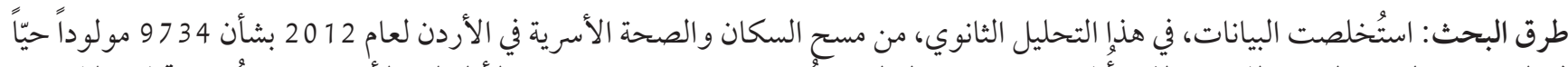

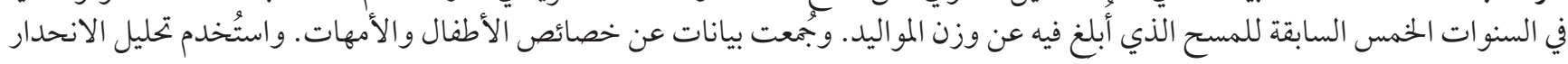

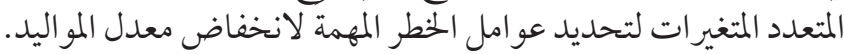




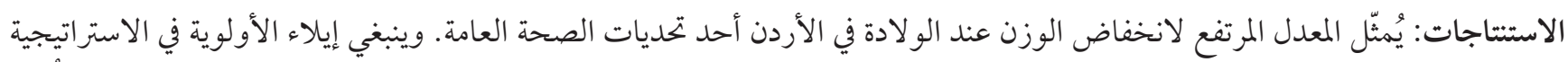

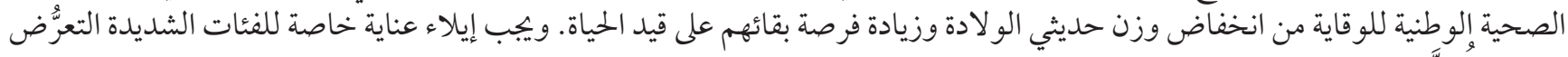
للخطر المححَّدة في هذه الدراسة.

\section{References}

1. International statistical classification of diseases and related health problems, 11th revision. Geneva: World Health Organization; 2018.

2. Low birth weight: country, regional and global estimates. New York and Geneva: United Nations Children Education Fund and World Health Organization; 2004.

3. Zeve D, Regelmann MO, Holzman IR, Rapaport R. Small at birth, but how small? The definition of SGA revisited. Horm Res Paediatr. 2016;86:357-60. https://doi.org/10.1159/000449275

4. Córcoles-Parada M, Giménez-Mateo R, Serrano-del-Pueblo V, López L, Pérez-Hernández E, Mansilla F, et al. Born too early and too small: higher order cognitive function and brain at risk at ages 8-16. Front Psychol. 2019;10:1942. https://doi.org/10.3389/ fpsyg.2019.01942

5. Ahishakiye A, Abimana MC, Beck K, Miller AC, Betancourt TS, Magge H, et al. Developmental outcomes of preterm and low birth weight toddlers and term peers in Rwanda. Ann Glob Health. 2019;85(1):147. https://doi.org/10.5334/aogh.2629

6. Islam MM. The effects of low birth weight on school performance and behavioral outcomes of elementary school children in Oman. Oman Med J. 2015;30(4):241-51.

7. Ratnasiri AWG, Parry SS, Arief VN, DeLacy IH, Halliday LA, DiLibero RJ, et al. Recent trends, risk factors, and disparities in low birth weight in California, 2005-2014: a retrospective study. Matern Health Neonatol Perinatol. 2018;4:15. https://doi.org/10.1186/ s40748-018-0084-2

8. Department of Statistics [Jordan] and ICF International. Jordan Population and Family Health Survey 2012. Calverton (MD): Department of Statistics \& ICF International; 2013 (https://dhsprogram.com/pubs/pdf/fr282/fr282.pdf, accessed 5 May 2020).

9. Setlur B. Project information document (appraisal stage) - JO-Badia ecosystem and livelihoods - P127861. Washington (DC): World Bank Group; 2012 (http://documents.worldbank.org/curated/en/806431468771281104/Project-Information-Document-Appraisal-Stage-JO-Badia-Ecosystem-and-Livelihoods-P127861, accessed 5 May 2020).

10. Rutstein SO, Johnson K. The DHS wealth index. DHS comparative reports No. 6. Calverton (MD): ORC Macro; 2004 (https:// dhsprogram.com/pubs/pdf/CR6/CR6.pdf, accessed 5 May 2020).

11. Department of Statistics [Jordan] and IRD/Macro International. Jordan Population and Family Health Survey 1990. Calverton (MD): Department of Statistics \& IRD/Macro International; 1992.

12. Department of Statistics [Jordan] and Macro International Inc. Jordan Population and Family Health Survey 1997. Calverton (MD): Department of Statistics \& Macro International; 1998.

13. Department of Statistics [Jordan] and ORC Macro. Jordan Population and Family Health Survey 2002. Calverton (MD): Department of Statistics \& ORC Macro; 2003.

14. Department of Statistics [Jordan] and Macro International Inc. Jordan Population and Family Health Survey 2007. Calverton (MD): Department of Statistics \& Macro International Inc.; 2008.

15. Donahue SMA, Kleinman KP, Gillman MW, Oken E. Trends in birth weight and gestational length among singleton term births in the United States: 1990-2005. Obstet Gynecol 2010;115:357-64. https://doi.org/10.1097/AOG.obo13e3181cbd5f5

16. United Nations Children's Fund and World Health Organization. UNICEF-WHO Low birthweight estimates: levels and trends, 2000-2015. Geneva: World Health Organization; 2019 (https://apps.who.int/iris/bitstream/handle/10665/324783/WHO-NMHNHD-19.21-eng.pdf?ua=1, accessed 5 May 2020).

17. Deshpande JD, Phalke DB, Bangal VB, Peeyuusha D, Sushen B. Maternal risk factors for low birth weight neonates: a hospital based case control study in rural area of western Maharashtra, India. Natl J Community Med. 2011;2(3):394-8.

18. Islam MM. Increasing incidence of infants with low birth weight in Oman, Sultan Qaboos University Med J. 2015;15(2):e177-83.

19. Alexander BT, Henry Dasinger J, Intapad S. Low birth weight: impact on women's health. Clin Ther. 2014;36(12):1913-23. https:// doi.org/10.1016/j.clinthera.2014.06.026

20. Martínez-Mesa J, Restrepo-Méndez MC, González DA, Wehrmeister FC, Horta BL, Domingues MR, et al. Life-course evidence of birth weight effects on bone mass: systematic review and meta-analysis. Osteoporos Int. 2013;24:7-18. https://doi.org/10.1007/ s00198-012-2114-7

21. King JC. Physiology of pregnancy and nutrient metabolism. Am J Clin Nutr. 2000;71:1218S-25S. https://doi.org/10.1093/ajc$\mathrm{n} / 71.5 .1218 \mathrm{~s}$

22. Whincup PH, Kaye SJ, Owen CG, Huxley R, Cook DG, Anazawa S, et al. Birth weight and risk of type 2 diabetes: a systematic review. JAMA. 2008;300(24):2886-97. https://doi.org/10.1001/jama.2008.886

23. Chomitz VR, Cheung LW, Lieberman E. The role of lifestyle in preventing low birth weight. Future Child. 1995;5(1):121-38. 
24. Das RN, Devi RS, Kim J. Mothers' lifestyle characteristics impact on her neonates' low birth weight. Int J Women Health Reprod Sci. 2014;2(4):229-35. https://doi.org/10.15296/ijwhr.2014.33

25. Abubakari A, Jahn A. Maternal dietary patterns and practices and birth weight in northern Ghana. PLoS ONE. 2016;11(9):e0162285. https://doi.org/10.1371/journal.pone.0162285

26. KramerMS. The epidemiology of adverse pregnancy outcomes: an overview. J Nutr. 2003;133(5):1592S-6S. https://doi.org/10.1093/ jn/133.5.1592S

27. Abu-Saad K, Fraser D. Maternal nutrition and birth outcomes. Epidemiol Rev. 2010;32(1):5-25. https://doi.org/10.1093/epirev/ mxqoo1

28. Black RE, Allen LH, Bhutta ZA, Caulfield LE, De Onis M, Ezzati M, et al. Maternal and child undernutrition: global and regional exposures and health consequences. Lancet. 2008;371(9608):243-60. https://doi.org/10.1016/So140-6736(07)61690-0

29. Restrepo-Méndez MC, Lawlor DA, Horta BL, Matijasevich A, Santos IS, Menezes AMB, et al. The association of maternal age with birth weight and gestational age: a cross-cohort comparison. Paediatr Perinal Epidemiol. 2015;29:31-40. https://doi. org/10.1111/ppe.12162

30. Aras RY. Is maternal age risk factor for low birth weight? Arch Med Health Sci. 2013;1:33-7. https://doi.org/10.4103/23214848.113558

31. Islam MM, ElSayed MK. Pattern and determinants of birth weight in Oman. Public Health. 2015;129(12):1618-26. https://doi. org/10.1016/j.puhe.2015.07.011

32. Ziadeh S. Obstetric outcome of teenage pregnancies in North Jordan. Arch Gyn Obst. 2001;265(1):26-9. https://doi.org/10.1007/ s004040000121

33. Ghaemmaghami SJ, Nikniaz L, Mahdavi R, Nikniaz Z, Razmifard F, Afsharnia F. Effects of infants' birth order, maternal age, and socioeconomic status on birth weight. Saudi Med J. 2013;34(9):949-53.

34. Restrepo-Méndez MC, Lawlor DA, Horta BL, Matijasevich A, Santos IS, Menezes AMB, et al. The association of maternal age with birthweight and gestational age: a cross-cohort comparison. Paediatr Perinal Epidemiol. 2015;29:31-40. https://doi. org/10.1111/ppe.12162

35. Bihoun B, Zango SH, Traoré-Coulibaly M, Rouamba T, Zemba D, Tahita MC. et al. Low birth weight and prematurity in teenage mothers in rural areas of Burkina Faso. J Preg Child Health. 2017;4:344. https://doi.org/10.4172/2376-127X.1000344

36. Martinson ML, Reichman NE. Socioeconomic inequalities in low birth weight in the United States, the United Kingdom, Canada, and Australia. Am J Public Health. 2016;106:748-54. https://doi.org/10.2105/AJPH.2015.303007.1

37. Makhija K, Murthy GV. Sociobiologic factors influencing low birth weight at rural project hospital. J Indian Med Assooc. 1990;88(8):215-7.

38. Cramer JC. Racial and ethnic difference in birth weight: the role of income and financial assistance. Demography. 1995;32:23147. https://doi.org/10.2307/2061742

39. Monteiro CA, Moura EC, Conde WL, Popkin BM. Socioeconomic status and obesity in adult populations of developing countries: a review. Bull World Health Organ. 2004;82(12):940-6. https://doi.org/10.1590/Soo42-96862004001200011

40. Pampel FC, Denney JT, Krueger PM. Obesity, SES, and economic development: a test of the reversal hypothesis. Soc Sci Med. 2012;74(7):1073-81. https://doi.org/10.1016/j.socscimed.2011.12.028

41. Malik S, Ghidiyal RG, Udani R, Waingankar P. Maternal biosocial factors affecting low birthweight. Ind J Pediatr. 1997;64(3):3737. https://doi.org/10.1007/BF02845207

42. Mohsin M, Wong F, Bauman A, Bai J. Maternal and neonatal factors influencing premature birth and low birth weight in Australia. J Biosoc Sci. 2003;35:161-74. https://doi.org/10.1017/s0021932003001615

43. Hughes IA, Northstone K, Golding J, the ALSPAC Study Team. Reduced birth weight in boys with hypospadias: an index of androgen dysfunction? Arch Dis Child Fetal Neonatal Ed. 2002;87:150-1. http://doi.org/10.1136/fn.87.2.F150

44. de Zegher F, Francois I, Boehmer AL, SaggeseG, Mu“ ller J, HiortO, Sultan C, et al. Androgens and fetal growth. Horm Res. 1998;50(4):243-4. https://doi.org/10.1159/000023284

45. Mittwoch U. Blastocysts prepare for the race to be male. Hum Reprod. 1993;8:1550-5. https://doi.org/10.1093/oxfordjournals. humrep.a137889

46. Qotob R, Mawajdeh S, Allosh R, Mehyar H, Majali S. The effect of prenatal knowledge of fetal sex on birthweight: a study from Jordan. Health Care Women Int. 2004;25:281-91. https://doi.org/10.1080/07399330490272769

47. Islam MM. The changing pattern and determinants of declining consanguinity in Jordan during 1990-2012. Ann Hum Biol. 2018;45(2):140-7. https://doi.org/10.1080/03014460.2018.1429655

48. Poorolajal J, Ameri P, Soltanian A, Bahrami M. Effect of consanguinity on low birth weight: a meta-analysis. Arch Iran Med. 2017;20(3):178-84.

49. Obeidat BR, Khader YS, Amarin ZO, Kassawneh M, Al Omari M. Consanguinity and adverse pregnancy outcomes: the north of Jordan experience. Matern Child Health J. 2010;14:283-9. https://doi.org/10.1007/s10995-008-0426-1

50. Bener A, Saleh NM, Salameh KMK, Basha B; Joseph S; Samson N, AlBuz R. The impact of the interpregnancy interval on birth weight and other pregnancy outcomes. Revista Brasileira de Saúde Materno Infantil. 2012;12(3):233-41. https://doi.org/10.159o/ S1519-38292012000300003 
51. Brhane M, Hagos B, Abrha MW, Weldearegay HG. Does short inter-pregnancy interval predicts the risk of preterm birth in Northern Ethiopia? BMC Res Notes. 2019;12(1):405. https://doi.org/10.1186/s13104-019-4439-1

52. Islam MM, Marium U. Twin births in Jordan: incidence, trends, risk factors and implications for under-five mortality: evidence from the 2012 Jordan Population and Family Health Survey. J Biosoc Sci. 2019;51(6):857-74. https://doi.org/10.1017/ So021932019000154

53. Jacobson LT, Dong F, Scheuermann TS, Redmond ML, Collins TC. Smoking behaviors among urban and rural pregnant women enrolled in the Kansas WIC program. J Community Health. 2015;40:1037e46. https://doi.org/10.1007/s10900-015-0029-x

54. Robinson O, Martínez D, Aurrekoetxea JJ, Estarlich M, Fernandez-Somoano A, Iniguez C, et al. The association between passive and active tobacco smoke exposure and child weight status among Spanish children. Obesity. 2016;24:1767e77. https://doi. org/10.1002/oby.21558

55. Balwicki Ł, Zarzeczna-Baran M, Wierucki Ł, Jędrzejczyk T, Strahl M, Wrotkowska M, et al. Smoking among pregnant women in small towns in Poland. Int J Public Health. 2016;61:111- 118. https://doi.org/:10.1007/s00038-015-0735-2

56. Kataoka MC, Carvalheira APP, Ferrari AP, Malta MB, de Barros Leite Carvalhaes MA, de Lima Parada CMG. Smoking during pregnancy and harm reduction in birth weight: a cross-sectional study. BMC Pregnancy Childbirth. 2018;18(1):67. https://doi. org/10.1186/s12884-018-1694-4

57. Zheng W, Suzuki K, Tanaka T, Kohama M, Yamagata Z, the Okinawa Child Health Study Group. Association between maternal smoking during pregnancy and low birthweight: effects by maternal age. PLoS One. 2016;11(1):e0146241. https://doi.org/10.1371/ journal.pone.0146241

58. Huang SH, Weng KP, Huang, SM, Liou HH, Wang CC, Ou SF, et al. The effects of maternal smoking exposure during pregnancy on postnatal outcomes: a cross-sectional study. J Chin Med Assoc. 2017;80:796-802. https://doi.org/10.1016/j.jcma.2017.01.007 